\title{
WestVirginiaUniversity
}

THE RESEARCH REPOSITORY @ WVU

West Virginia Agricultural and Forestry Experiment

Davis College of Agriculture, Natural Resources

Station Bulletins

And Design

$1-1-1968$

\section{Effects of ionizing irradiation on the xylem derivatives of Pinus echinata Mill.}

Alexander Clark

J. R. Hamilton

Follow this and additional works at: https://researchrepository.wvu.edu/ wv_agricultural_and_forestry_experiment_station_bulletins

\section{Digital Commons Citation}

Clark, Alexander and Hamilton, J. R., "Effects of ionizing irradiation on the xylem derivatives of Pinus echinata Mill." (1968). West Virginia Agricultural and Forestry Experiment Station Bulletins. 567T.

https://researchrepository.wvu.edu/wv_agricultural_and_forestry_experiment_station_bulletins/678 @ WVU. It has been accepted for inclusion in West Virginia Agricultural and Forestry Experiment Station Bulletins by an authorized administrator of The Research Repository @ WVU. For more information, please contact ian.harmon@mail.wvu.edu. 

Digitized by the Internet Archive in 2010 with funding from

Lyrasis Members and Sloan Foundation 

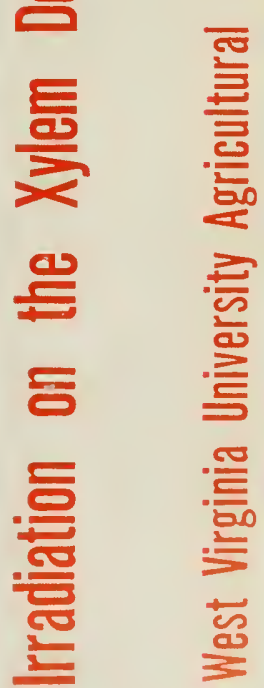

흘 


\title{
THE AUTHORS
}

Alexinder Clark III is Wood Technologist, Sontheastern Forent lixperiment Station, U. S. Forest Service. J. R. Hamilton is Wool Scientist, West Virginia Agricultural Experiment Stations.

\section{ACKNOWLEDGMENT}

Research wats conducted under the auspices of the U. S. Atomic Energy Commission, Division of Biolegy and Medicine, in copperation with West Virginia University, College of Agriculture and Forestry Contract No. AT - (40-1) - 3100.

\author{
ITest Virginia University \\ Agrioultural Experiment Station \\ College of Agriculture and Fonestry \\ A. il. I'aniandingham, Director \\ Morgantoran
}




\section{EFFECTS OF IONZZING IRRADIATION ON THE XYLEM DERIVATIVES OF PINUS ECHINATA MILL.}

Alexander Clark III and J. R. Hamilton 
mattherl wh that the dirertion of the reactor could be asectaned later. Two longitudinal strips. measuring one inch in the tangential dircedion and of sulticient lenglt in the radial direction to include the 1958 through 1963 increments. were remored from each bolt, one on the sicie towart the seactor and the other on the side diamenically opposite. In this way, eate nee was sampled at len locations-live height levels and two sides at each leight level.

Within each simple the specific tisstes of interest were those lommed lluning ratiation expontue in 1959 and 1960 and ampanable tissmes in lle logs increment. Becaure usable commol trees would have of necessity becu located at some distance lrom the irradiated trees, the 1958 increnent in each tree was used for comtrol purposes.

Three longitudinal sections 100 microns in thickness (radial elireciom), were cut on a sliding microtome from the selected ammal increments. Care was exercised, by frequent comparisons between transverse sections prepared for this purpere and the block being cut, to insme that

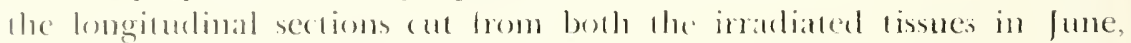

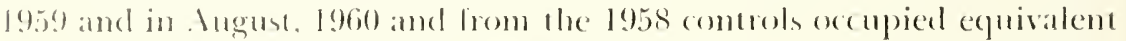
within-indement positions. These sections were callatogued and stored in distilled water for a maximmon of thee days.

Jensile test sperimens were punched from the wet sections with a sperally comstructed die 10 linal sise ol $0.12 \times 9.35$ inches. Cane was laken 10) dimbinate cross glatin. The saturated specimens were stressed over a 1.52 inch length at an elongation rate of 0.005 inches per minute using an In-

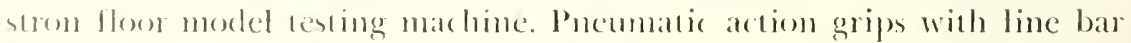
grip fares were ased to climinate slippage during the test. The tensile load

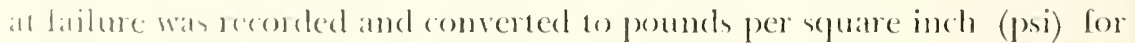
catels yee imen. The arerage of the results of the three tests was used as a meastme of the fensile strength in each increment and location sampled.

Aler lesting, cath micro-tensile lest specinen wats macerated in equal panc of glatial alcelic ac id and lydrogen peroxide. Measurements were mate of wall thickness, funen dianeter and length of ren ranclomly sedected, issolated, vertical trateleids asing a projection microscope and (alibualcel mole. Total lengths and the dianeter and wall thickness midwas of the cell were reorded. Data hom the theespecimens were averaged and uscel as a measume of the llatheid characteristics for each increment in racl) loxation.

In analyoing the data two sepanate analyses of variance were executed. I he lirst, a prelininaly analysis made alter data from two trees had been collecterl, emplenced a phlit-phol design and was used to determine whether the diming of inatiation with respect to gowwh period probluced differ- 
ential effects and whether there was a difference between sides. The differences due to trees, growth periods, and sides constituted the whole-plot while the difference due to height were sub-plots. Each of the characteristics was analyzed separately.

Based on results of the preliminary analysis, the remaining two trees were sampled only on the side nearest the source. The second analysis of variance also made use of a split-plot design and wirs used to determine if there was a significant degree of variation among the four exposed trees using only the data from the side closest to the source. Effects of irradiation and effects of trees constituted the whole-plot and the differences due to height were sub-plots.

After the first analysis it was noted that the error for the whole-plot was consistently smaller than the error for the sub-plot. Since this can occur only by chance, both error terms were considered to be estimates of the same population variance. Consequently the sums of squares were pooled in order to obtain a more accurate estimate of the population variance (6). The imadiated tisotes produced in June, 1959, and in August, 1960, were analyzed separately for each variable comsidered.

\section{Results and Discussion}

The effects of ionizing radiation on shortleaf pine tissues may be noted in Figure 1 as zones of irregularly shaped cells occurring in the laterood of the 1959 and 1960 increments. Tracheids differentiated during irradiation appear to have larger Immina, thimmer walls, and at distorted shape in contrast to those produced under normal conditions. As reported by several investigators $(1,2,3)$, the cell abnormalitic associated with imadiation have distinct boundaries. Rapid changes occul both with inreption and cessation of irradiation.

Imadiation churing August, 1960 caused the formation of amomalous tissues in the latter portion of the lateworl at earh height lesel. In conttrast, the location of aherrations associated with the June, 1959) irraliation was not constant within the increment but varied with height. From the lowest point sampled to approximately 50 per cent of toral height the

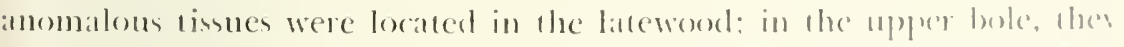
were observed in the batter portion of the earlywond (Figure? dependency on height was noted on both sicles of all trees eximnincel. It in evident that the June burst of irratiation ocoured at the lime the studs

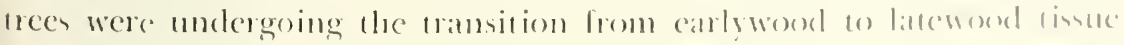
production since latewood intiation hat been noted on begin in ants June and progress alcopetally at a graclual rate (9). It hat hecen prostu

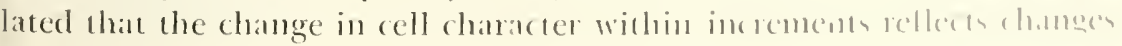


in anxin concentration associated with changes in the rate of shoot elongation (1). Resules obtained here suggest that irradiation did not disturb

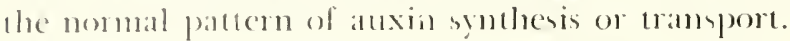

beatres of the difference in whin-increment location of irradiated

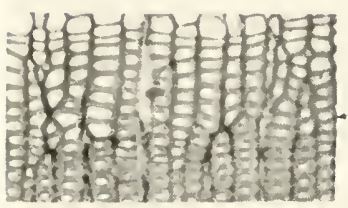

$\hat{厶}$

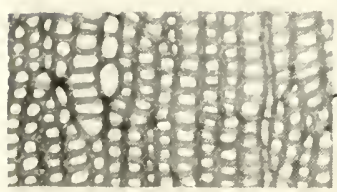

B

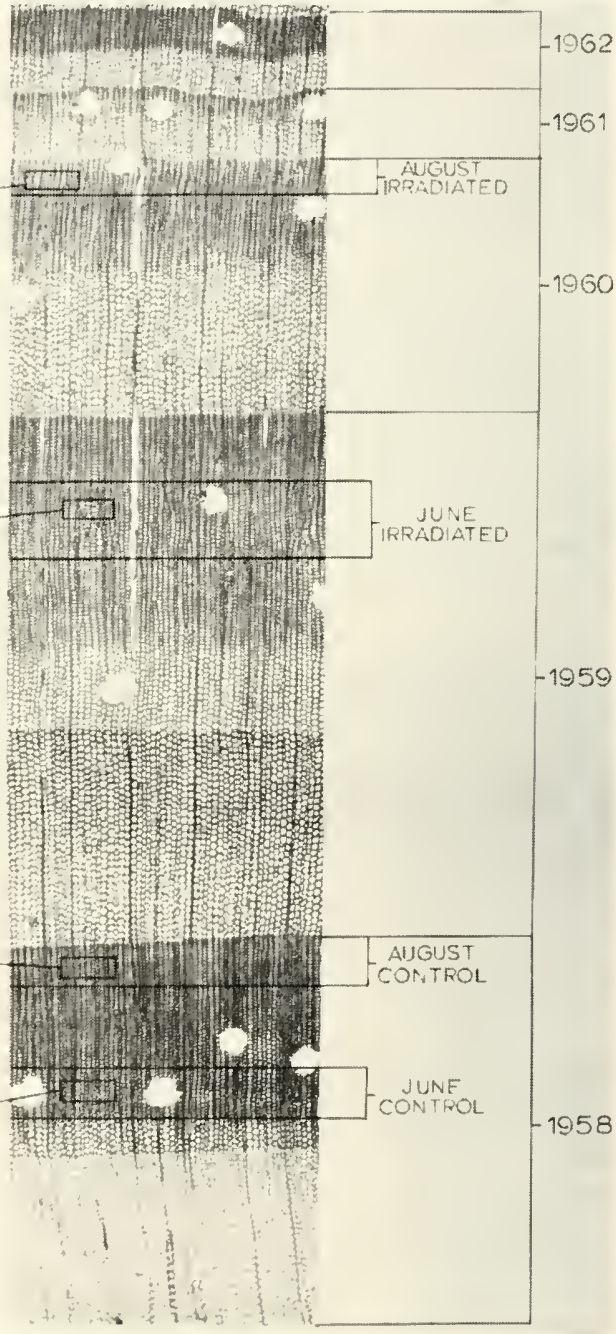

Higmere I. The lowation of sompling arras at the lowest height lezed

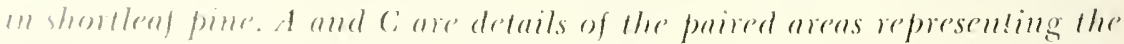

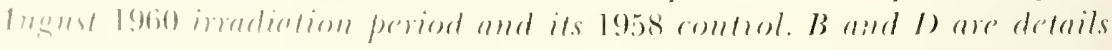

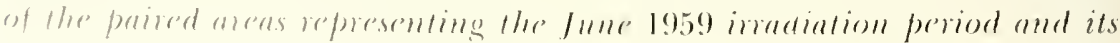
1958 control. (composite photomicosgenph x 50, detail x 190) 
tissues associated with the June period of in radiation. the test specimens were located in the latewood in the lower half of the trees and in the earlywool in the upper hall of the trees. Nll of the specimen, reperenenting the August, 1960 irradiation period were located in the latewoon.

In the preliminary analysis, orthogonal comparisons revealed that there was a difference between imadiated and control tissues, and that the effects in June were not the sume as those in dugust when wall thickness, lumen diameter, and tensile strength were considered (Table I). In addition, there was no significant difference between the side nearest and the side opposite the reactor which could be attributed to indaliation. based on these results, the subsequent analysis treated the 1959) and 1960) irradiation periods as distinct events. They were analyzed separately, and the properties were detemined only on the side of the trees toward the source.

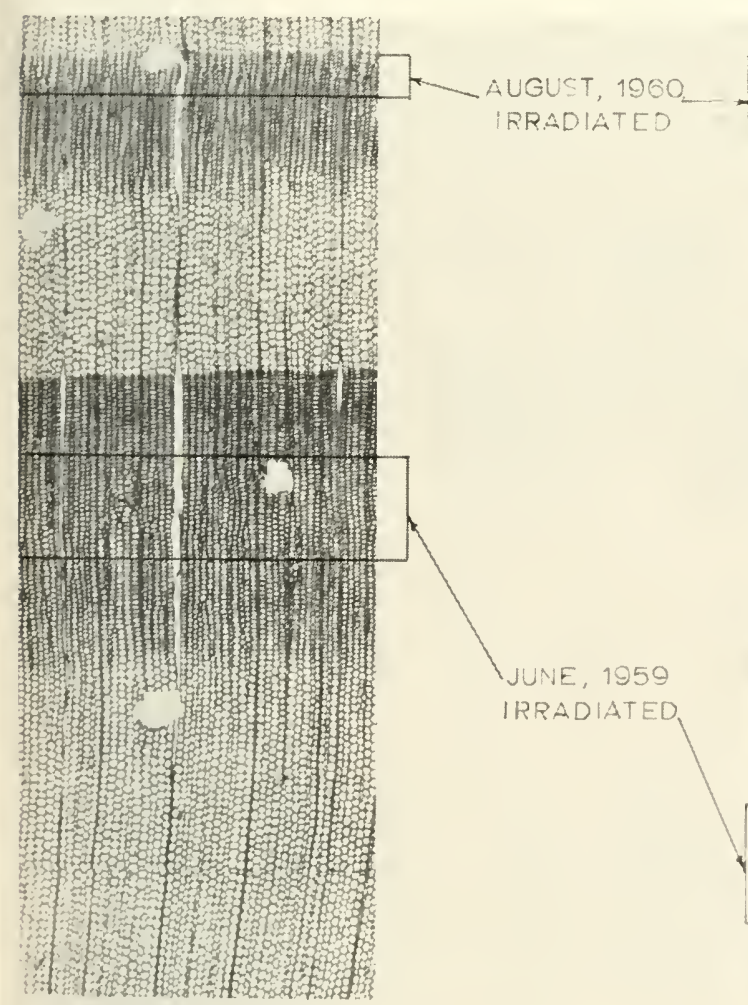

1st. HEIGHT LEVEL

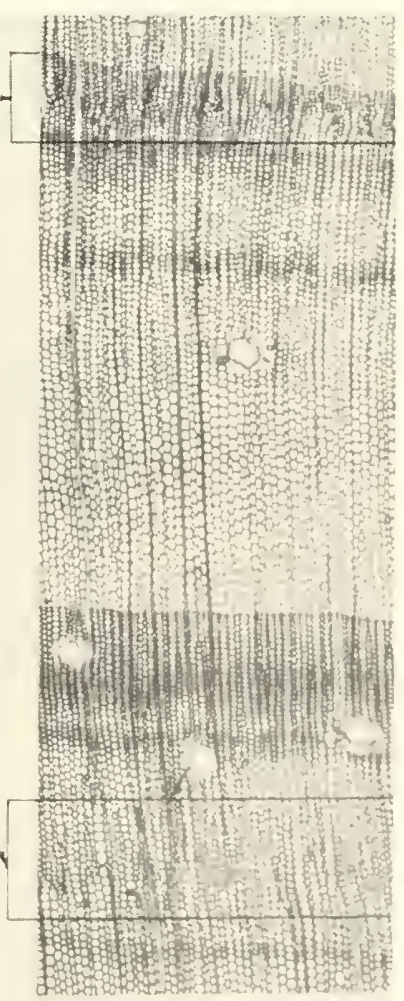

5th. HEIGHT LEVEL

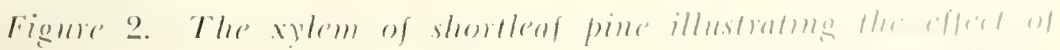

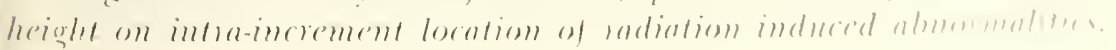




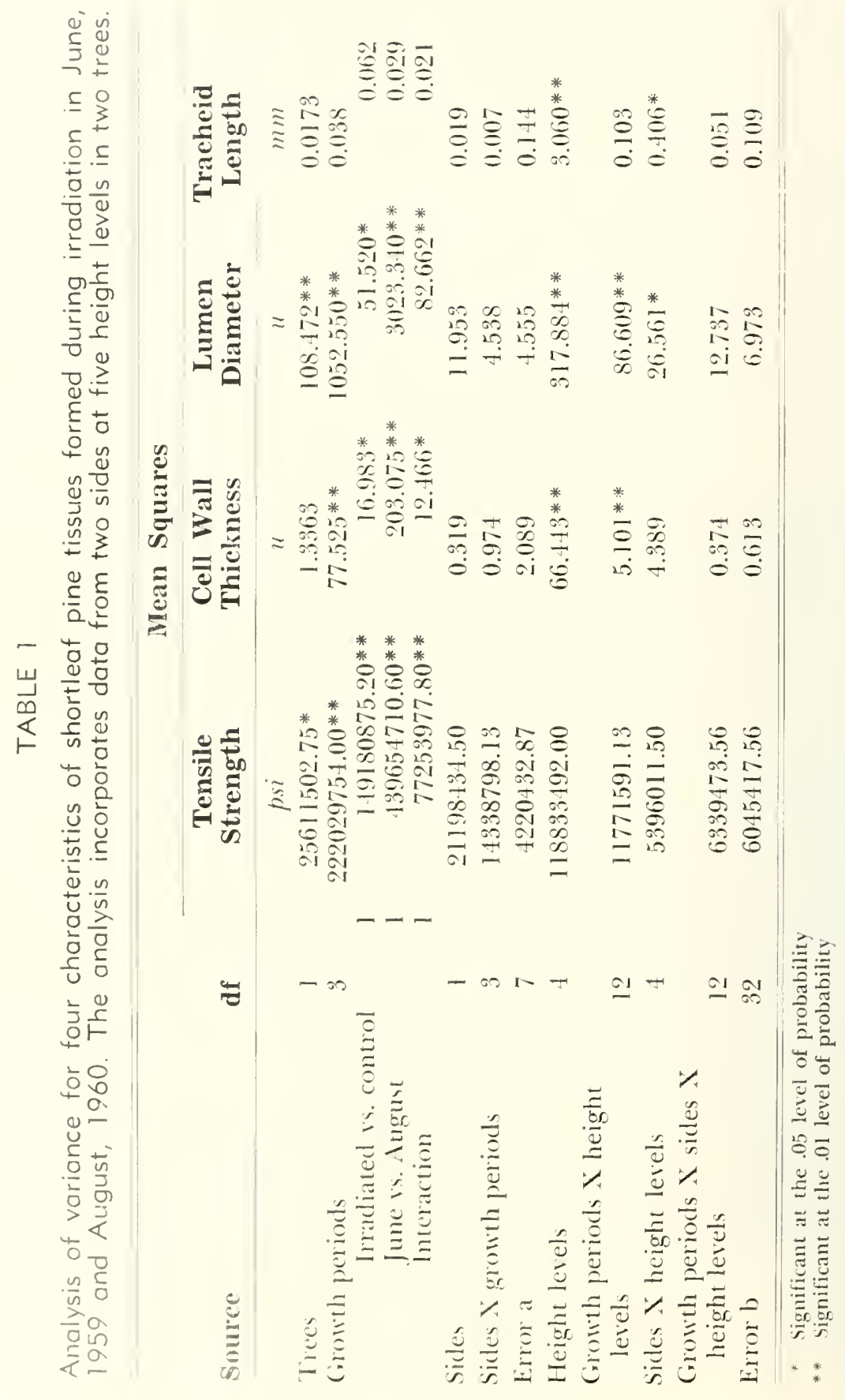


Tracheid wall thickness and lumen diameter were significantly altered by the August, 1960 irradiation (Table 2) but not by June, 1959 irradiation (Table 3). Tracheid length was not affected in cither year. When all sample locations in the four wees were considered collectively, a 16 per cent reduction in all thickness and a 31 per cent increase in humen diameter were noted in the 1960 increment. Similar resuls have been reported in Pinus rigida and $P$. echinata (3), but, in these studies, signilicant reductions in length were also noted. In the present study only small and non-significant reductions in length were recorded. Lark of agreement may stem from inadequate sample size in the present suldy.

In both the preliminary analysis and the analyses of four trees it was shown that there was a difference in the effect of imaliation in June, 1959 and August, 1960. These differences may have resulted from three contributing factors. The 1960 irradiation was 55 per cent greater than that of 1959, a factor which in itsell may account for the differential response. It should be remembered, however, that the 1960 exposwre was in addition to that which had been accumulated during 1959. The possibility also remains that there is a difference in radiosensitivity between differentiation of earlywood and latewood tissues and in the processes which govern their formation. The changes which occurred in the latewood resulted in cells which had characteristics resembling earlywood cells-thinner walls and larger lumina.

Strength in tension parallel to the grain was also affected by irradiation (Table 4). As with cell characteristics, significant effects were noted in the 1960 increment only (Tables 2 and 3), where maximum arerage tensile strength was 11,154 psi or 26 per cent less than that of the ontmol.

In each analysis a significant tree-to-tree difference was inticalcal. On the basis of an examination of the per cent change between imaliated and control specimens for each wee, the dilferences appear to be a rellec tion of inherent tree differences rather than differences in ralialion itesponse.

All four of the chancteristiss measured varied significanty with height in both imadiation periods (Table 2 and 3$)$. The changes wiol

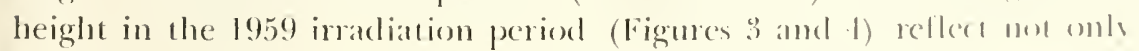
changes associated with height per se but also the change in within-incte-

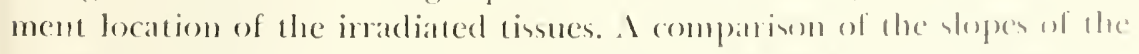

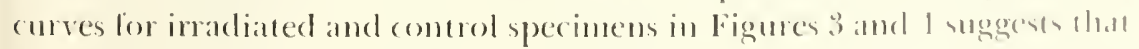
the significant height effect was artually due to the momal latritton

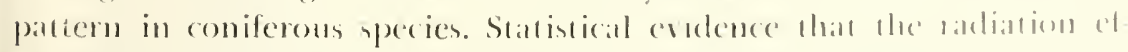

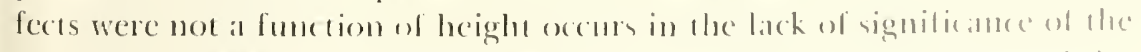
radiation versus control and height level interation (Tilder "2 and is) 


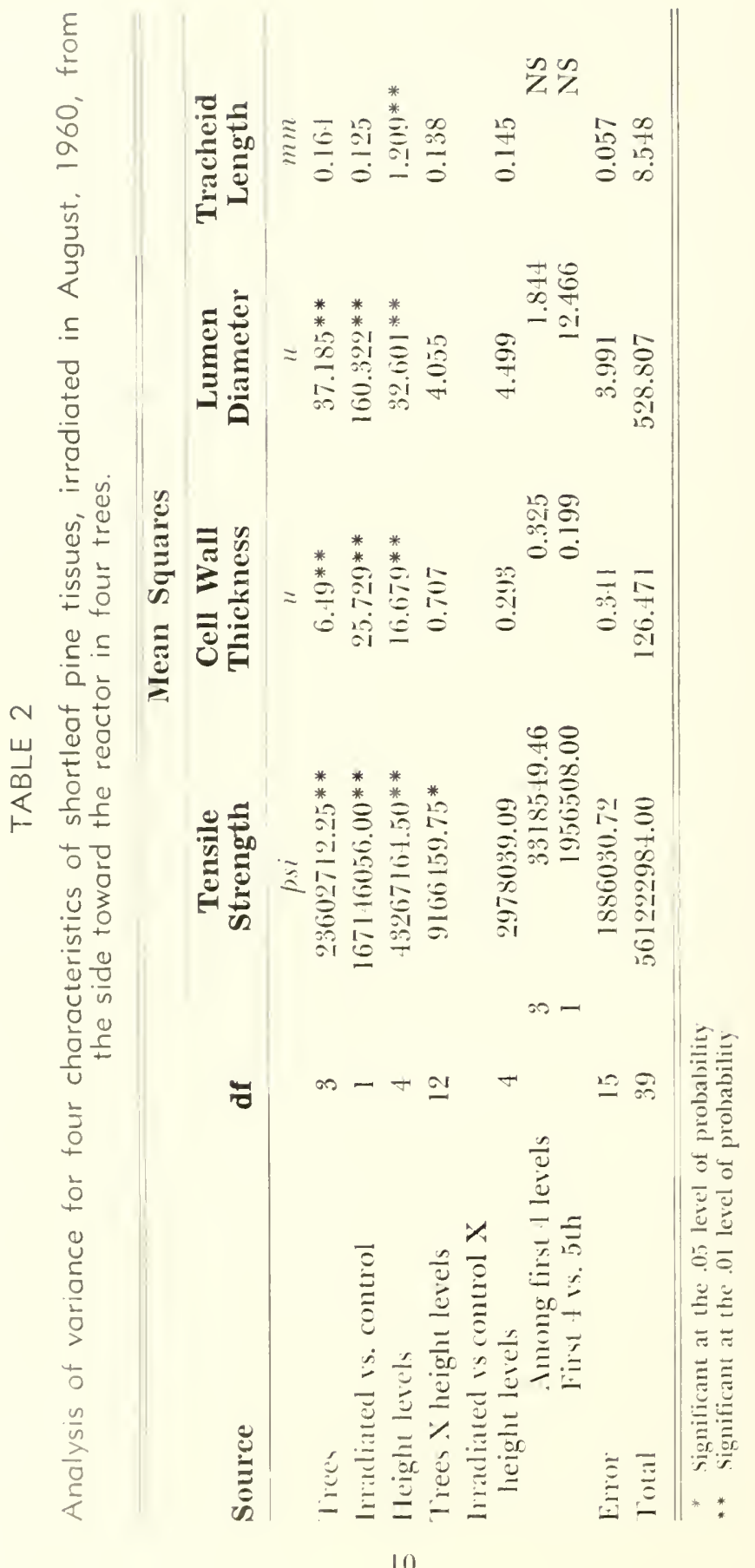




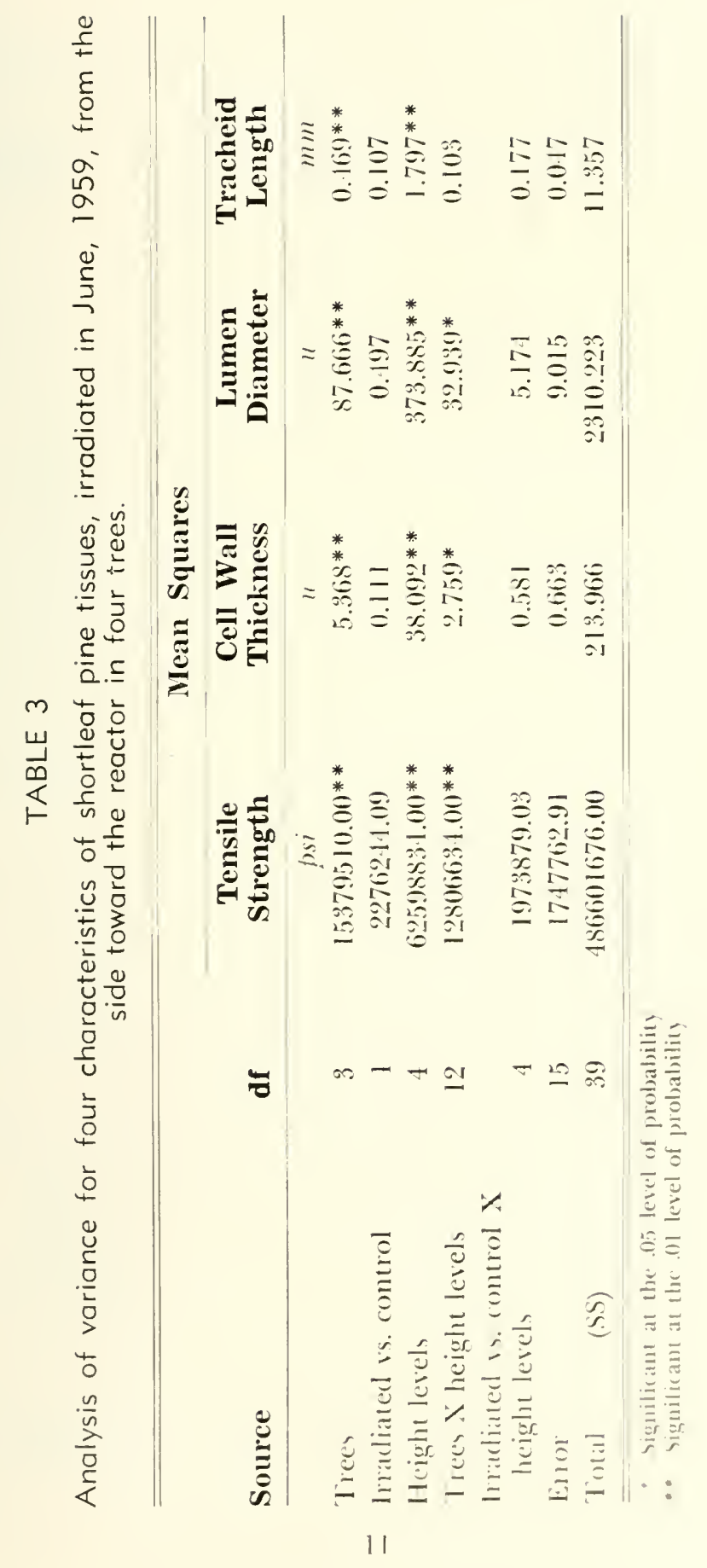




\section{TABLE 4}

Means for four characteristics of shortleaf pine tissues formed during irradiation and in control tissues.

\begin{tabular}{|c|c|c|c|c|}
\hline Item & $\begin{array}{c}\text { Tensile } \\
\text { Strength }\end{array}$ & $\begin{array}{c}\text { Cell Wall } \\
\text { Thickness }\end{array}$ & $\begin{array}{c}\text { Lumen } \\
\text { Diameter }\end{array}$ & $\begin{array}{l}\text { Tracheid } \\
\text { Length }\end{array}$ \\
\hline & \multicolumn{2}{|c|}{1959} & 9 & $m m$ \\
\hline Control & 8063.2 & 6.0 & 27.8 & 3.2 \\
\hline loradialled & 7586.0 & 6.1 & 28.0 & 3.1 \\
\hline bifference & 477.2 & 0.1 & 0.2 & 0.1 \\
\hline Per cent dhange & 5.9 & 1.8 & 0.8 & 3.3 \\
\hline & \multicolumn{4}{|c|}{1960} \\
\hline Control & 15512.6 & 10.2 & 13.1 & 3.3 \\
\hline Inadiated & 11451.2 & 8.6 & 17.1 & 3.1 \\
\hline Dilference & 1088.4 & 1.6 & 4.0 & 0.1 \\
\hline Per cent change & -26.3 & -15.7 & +30.6 & -6.1 \\
\hline
\end{tabular}

Further statistical examination by means of orthogonal comparisons (Table 2) also confirms the uniformity in the distribution of radiation effects in the tree boles. This conclusion is not in agreement with the reports of others (8) who suggest that radiation effects are not uniformly distributed throughou the boles of trees but are conditioned by proximity 10 the living crown.

In addition on the cell aberrations which were evident from the quantitative measurements, other abnormalities were frequently encountered. All irmaliated tissues were composed of cells which were very irregulas in cross sectional outline, reflecting unusual tateral expansion which appeatred to be occasioned by an increased lrequency of cambial additions and deletions. Such abuomalities have been related to an enlargement of medullan! ray cells in Pimus momophyllo (1). When individual rells were observed in longitudinal section, other curiosities were apparent. The frequency of bifurations was increased greatly over that which is ustatly observed in shortleal pine. They were more extensive, at times involving one-hall of the cell iength (Figure $5 \mathrm{~A}$ ), and were considerably unce incegulat (Figure 5l3). Many tracheids were penetrated by holes of ringing sire which showed some evidence of secondary wall development (Iigure 5C) resulting in a cylindrical formation. These structures extendcol Ior some distance in contiguous cells in the radial direction. Formations similar wo these known an trabeculac occur requently in Chamae( paris mortkntemsis and wo a linited extem in Pimus monticola (5). The tomation of trabeculate has been related to the penetration of fungal phite in the cambium. 


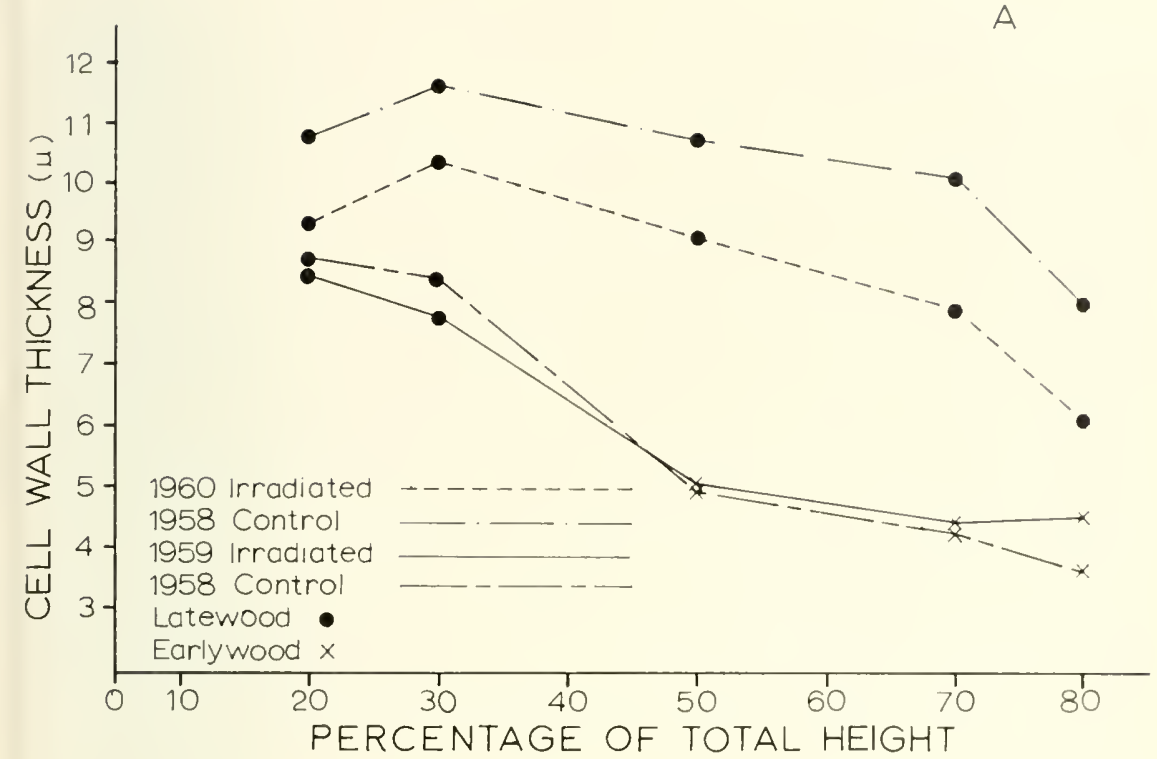

B

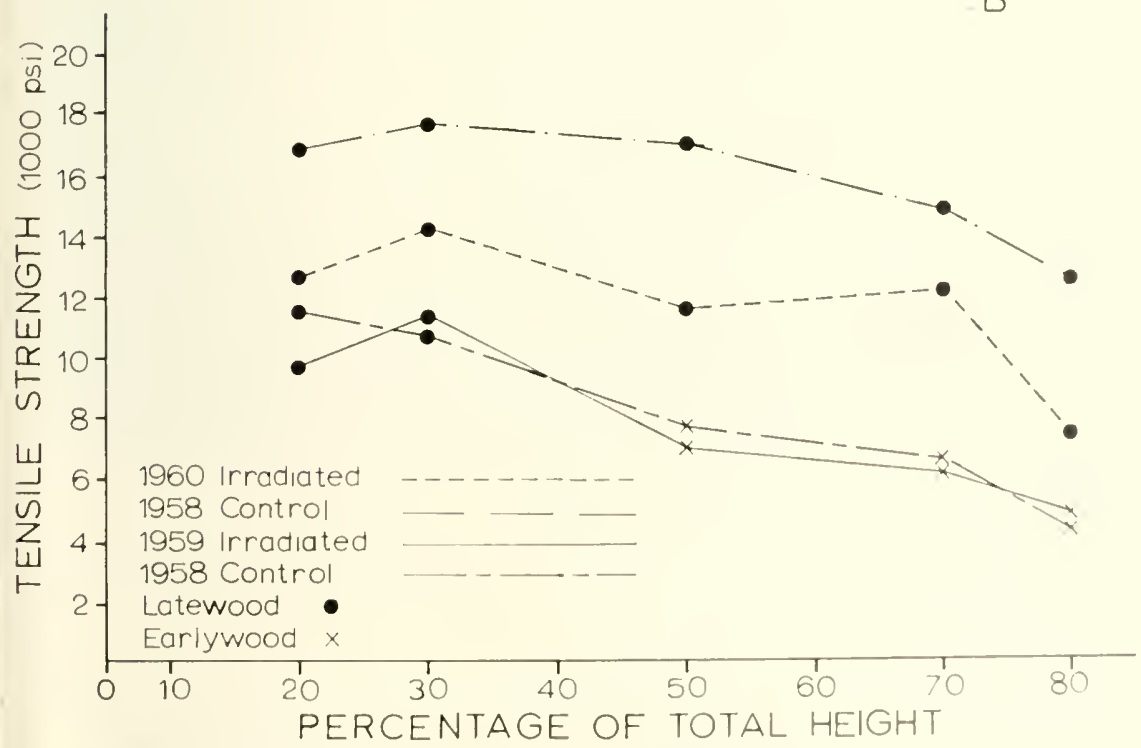

Fignve 3. The variation of rell atall thickness (A) and longitndimal tensile strength (B) with height in control and irmalinted shortleaf pune. 

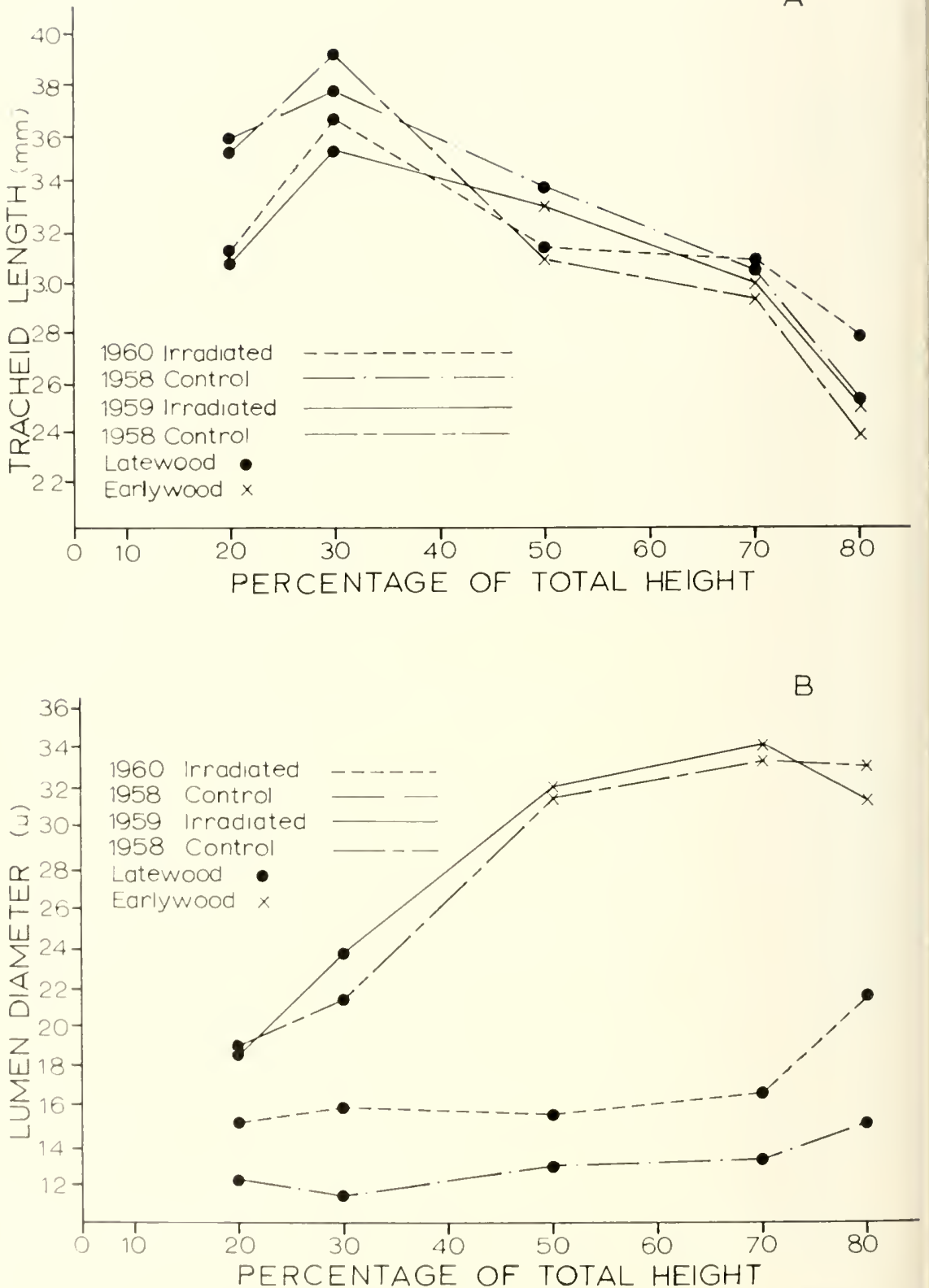

rigure i. The variation of tracheid length $(A)$ and lumen diameter (B) will height in combol and irradiated shorlleaf pine. 

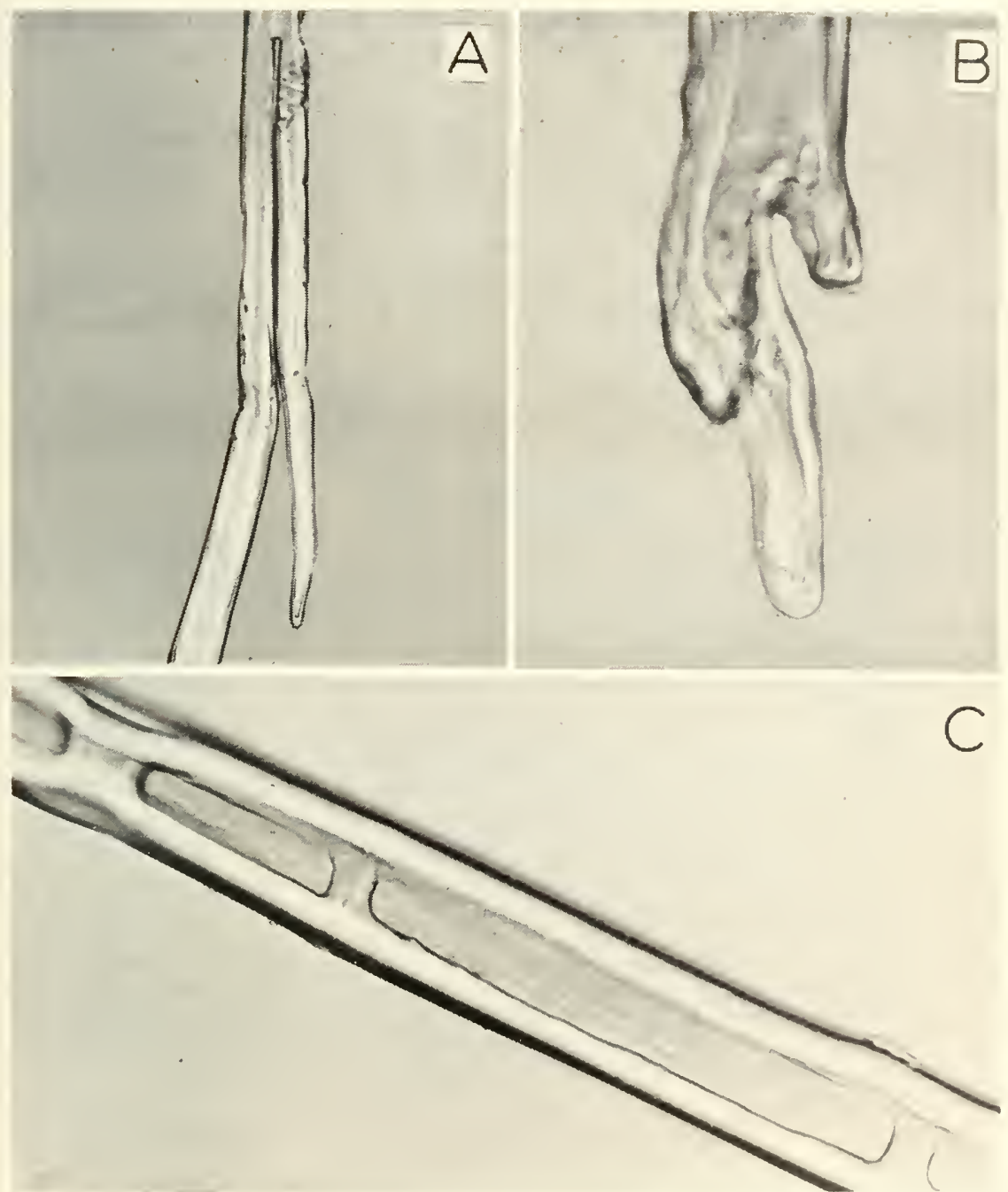

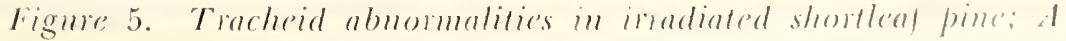
and B extensive and irregnlar bifurations (. 800$)$ : C: abmommal secondary wall formations $(x 1200)$.

\section{Conclusions}

The data presented in this bulletin appear to justily the lollowing conclusions:

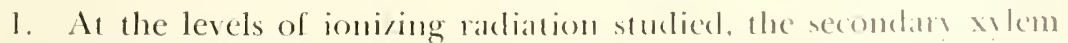
of shortleat pine is subject to radiation ineluced changes. Ithe 
changes are mniformly dismibuted in the tree boles; no effect of height or of orientation with respect to the direction of the source were noterl. The obser ved changes appear to be superimposed on the nomal patterns of variation which characterize this species.

2. Initial exposure of 900 rads was 10 ot sufficicnt to cause changes in wall thickness, lumen diameter or length of vertical tracheids. bowerer, exposure the following year to 1,400 rads caused meatsurable changes in two cell characteristics and tensile strenght.

3. Following exposme 10 accumblated exposures as great as 2,300 rads a telatively rapid return to nomal cell production and dilferentiation occurs.

\section{LITERATURE CITED}

1. Mrandenburg, M. K., H. I. Mill, W. II. Richard, and L. M. Shields, 1963.

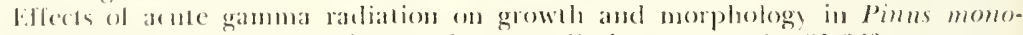
phyllo forr and Ferm. (Pingen P'ine). Radialion Bol. 22 (3):251-263.

2. Chesies. 1. 11. 1963. Anatomical variations in the secondary sylem of Quercus alba

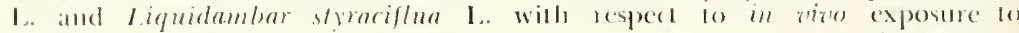
gamma-nentron adiation. Graluate Thesis. Iniversity of Georgia, Mthens. Georgia.

3. Ilanilion. J. R. 19t3. Characteristirs ol tracheids produced in a gamma and gammanemtrom corvironment. For. Prod. Jonr. 13: 62-67.

4. 1.arson, I'. R. 1960). I phisiological comsideration of the springwood-summerwood Iransilion in red pine. Fones science 2(2): 111-121.

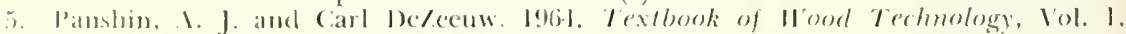
(Second Fdition) McGraw-llill Book Company, Inc. New York.

6. Plat1, R. B.. and J. I. Molubacher. 1959. Studies in radiation ecology: I. The program of studs. Bull. Ga. Acad. Sci. 17: 1-30.

7. Stcel, R.(.1) and I. II. Torrie. 1960). Primciples and Procedures of Statistics. If(raw-llill look Company, Inc. New York. pp. 234.

8. Wordwell, G. M. and Niller. 1963. Chronic gamma radiation alfects the distri-

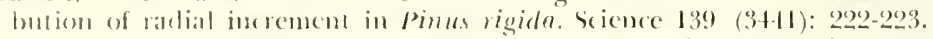

(i. Young, H. F. 1952. Differential time of diange trom earlywoorl to latewood along the boles of yeurg lobleslly pine trees. Jour. For. 50) (8): (614-615. 



